\title{
Studying King Lear: An Ecocritical and Ecofeminist Reading
}

\author{
Shivangi Kanojia \\ M.Phil Research Scholar \\ Department of English \\ University of Delhi \\ New Delhi, India \\ shivangikanojia@yahoo.com
}

\begin{abstract}
This paper analyses William Shakespeare's tragedy King Lear through the theory of Ecocriticism and seeks to understand Ecophobia - the fear of Nature. Lear's act of reducing Nature to an object through which he is deriving natural resources stems from his deep-seated animosity with the idea of women as independent entities. His feud with Cordelia and inability to see through the evil mechanisms of Goneril and Regan can be attributed to his unwillingness to surrender control of the land and to Nature. His failure to accept Cordelia's refusal to partake in his structure of power and authority can be read as his phallic anxiety in surrendering to Nature and women.
\end{abstract}

Keywords: Ecocriticism, Ecofeminism, Nature, King Lear.

Introduction

An Ecocritical study of King Lear has a twin fold effect by arming Shakespearean studies with the environment's vocabulary and providing a way to move beyond symbolic and thematic readings concerning Nature's representation in the play. Ecocriticism, as a discipline, is often scrutinized for the far-reaching practical employment of its theories. Scholars have 
often debated the difference between Ecocriticism and other environment-related studies. Ecocriticism takes the natural world as an essential entity rather than just a thematic study. It aims at making connections between the world of man and Nature by partaking in cultural variation. The problem resides in the fact that thematic discussions of life are relatively new, while its employment in Shakespearean studies is an even more unique phenomenon. Shakespeare was writing in an age that was not conscious of environmental crises like modern-day writers- Leslie Marmon Silko or Edward Abbey's writings are explicitly tackling. Therefore, we cannot just look at Ecocriticism as the study of natural things or Nature in literature but rather, more in the space of a theory that understands social, historical, and ideological framework of Nature.

By the fifteenth century- time in which Shakespeare was writing- there were considerable changes in man's relationship with the natural world. During this period, there was an active exploration of unexplored foreign lands, empire-building, and its subsequent effect in the form of imperialism, which was humanity's first attempt at controlling the natural environment. The world was getting smaller, predictable, and something that could be mapped, and this resulted in changed social relations, which constructed new ideas about space. In King Lear, space is needed to establish ideology and create boundaries in a shrinking world unbound. Therefore, when Lear loses control of his kingdom's natural environment, everything crumbles - home, power, position, identity, and sanity, which are in opposition to the natural world of the play.

Nature and Humanity

While studying the sections about Ecophobia in the text, an important question arises: In what ways does Nature have the upper hand over human-made 'constructed' structures of power? The interplay of power, authority, and control assumes the significant role in deciding 
the stance of the ecocritical perspective, such as the crumbling down of hitherto enjoyed, and privileged kingship is demonstrated in the scenes enacted in domesticated and natural areas, alike. The compulsion of being pushed out of his habitat/home, aggravated by Goneril and Regan's ingratitude and cruel hospitality, is weighed against inexplicable and unpredictable violent stormy thrashing, which manifests fear of environmental changes. The unpredictability is shared in both human and natural domains, but the degree to which it is exercised and functions are different. The fundamental distinction between the human and natural domain comes with the ability to transcend temporal and spatial framework, which accommodates Nature and evades humanity. This identification of transience of human life lends itself to Ecophobia's critical purview by getting subsumed under fear of natural disturbances. The 'nothingness' of mortal life is set against the natural environment's grandness, by the unsettling ecophobic rhetoric in the text under reference.

The ecological crisis paves a way to chart out essential discourse related to identity and go on to merge with sanity and existence. The only prerogative which at least superficially kept Lear united with his daughters was land under Lear's kingship. When it was passed down to Goneril and Regan, it gave way to Lear's failing sense of himself and the world around. The matter of dividing the land is not just personal, here, but it becomes a site for self-reflection probing in the realms of psyche and individuality. He senses an incomprehensible split in himself and voices out his state in these words-

Does any here know me? Why, this is not Lear.

Does Lear walk thus, speak thus? Where are his eyes? (1.4.217-18)

The utterance by Lear, "Who is it which will tell me who I am?" (1.5. 221) questions and brings forth the sense of split in Lear that brought on his madness and inability to own a foresight of the implications of his actions. The same is explicitly demonstrated when he 
exclaims, "O, let me not be mad" (1.5.43). In King Lear, Nature becomes that internal and external force, which acts not just from within, but from outside, too. In its representation of bare reality, the reduction of men to bestiality gets symbolized in the stripping away of clothes to a point where Lear says, "Man's life is cheap as beast's" (2.2.456). In the natural realm, the life of a man is no different from a beast. Lear's situation resonates with an animal who finds himself unsheltered, houseless and living without material benefits. The rejection of Nature's authority is portrayed through making divisions on a map as a voiceless substitution to see Nature as a passive entity, with no visible control. In Act 1, Scene 1, Lear describes his kingdom's division as materially realized in possession of lands.

The compelling title conferred upon the daughter just by scaling lines on a paper map demonstrates the seemingly thoughtless and straightforward exercise of dividing one's own material identity, which in a way makes him pay for his utter neglect of words with no outward appearance. Stricken with fear, Lear says- "(Y)ou (i.e., Nature) owe me no subscription, / Here I stand your slave." $(3.2 .18,19)$ The self-proclaimed "every inch of a King" (4.6.106), who gave away his sovereign authority, power, and land, was subjected to utter distraught at the hands of violent storms. This sudden change in identity from master to slave, and from nurturer of the kingdom to be nurtured by Nature in the way of acquiring reason during his bouts of madness, demarcates a dynamic relationship between human and Nature, changing the point of fulcrum in their active engagement.

Division of land and objectification of Nature

In his excessive pomp/show of power, Lear divides what is "indivisible" (Foakes 18) and problematizes the idea of Ecocriticism in the text by resorting to sharing and escaping the Nature since it refuses to fit into human-made structures. The tangible form of Nature, i.e., land, becomes part and parcel of the invading missions in its negotiable presence. The 
property becomes a physical signifier of authoritarian power. The objectification of Nature is marked by geographical boundaries, which becomes a recurring index of one's physical identity. However, no sooner than this all takes place, Nature, in its violent, active manifestation, subverts the "status quo" (Foakes 28), bringing the King to a houseless vagrant position. In this presentiment, a radical critique of political power and social injustice has been made in various speeches, as shown on the screen.

The play reflects a transition from an old order to a new one, as happened in Keats's Hyperion, observing the world in flux and subjected to change. The translation of pitiable human suffering into the psychological domain, juxtaposed with sublime and fear-invoking stormy skies, reminds us of Romantic individualism, which embraces Nature in its crude and majestic actions. As per the ecological study of the text, the horror in Lear is of displacement and dis-entitlement, which makes his situation horrific, and this horror is nothing but Ecophobia dramatized (23).

The multifaceted approach offered by Ecocriticism enables us to see Nature as being the foster parent figure to outcasts and humiliated characters of Edmund, as an illegitimate son; Kent, a banished court-counselor; Lear, as a thwarted mad King; Edgar, as the poor Tom; and Gloucester, as a blind traitor. The humanization and guidance of Lear by the fool and Nature are indicative of Cordelia's redemptive qualities, to forget and forgive. This transference of virtuous attributes such as endurance, patience, and forgiveness from the natural environs to female figure brings in ecofeminist debate. When viewed under the ecofeminist lens, resources obtained from Nature get commodified, and with the affection of Cordelia, the idea of the subject being the "other" comes into play. Thus, both Nature and women have been "othered" by humanity, denoting Lear's figure but later saved by their redemptive presence. 
Ecophobia and fear of women

As re-iterated by Plumwood, "Western culture's oppression of nature can be traced back to the construction of the dominant human male as a self fundamentally defined by its property of reason. She goes on by placing reason in direct opposition to Nature and how it represents a female body, their emotions and biological processes (13). Western thought grounds the oppression of women in women's closer association with Nature in terms of body, emotion, and reproduction. Women are perceived as the caretakers of the environment by tending to the domestic role of nurturer. Western dualistic thought can be traced back to Greek myths of Gaia's supplantation by male deities; "the biblical account of creation giving humankind dominion over nature but only man the power to name both woman and animals"; or representation of "women as more emotional, embodied, and accordingly closer to nature rather than culture" (Y Kao, 6). This perspective raises concern over a socially constructed notion that identifies women as life sustainers.

In King Lear, all the main characters, to some extent, contribute to a pragmatic view of Nature. It is perceived as a space that must be controlled, and if done otherwise, it becomes a space of chaos. John Danby locates Lear, Gloucester, Albany, and Kent in the "orthodox" view of Nature, which is "orderly, benign (but punitive), and connected with custom, reason, and religion" (19). He places Edmund, Cornwall, Goneril, and Regan as being "indifferent to social order and customs and at worst amoral and rapacious." He sees Cordelia as "standing for Nature herself" (19). Because of this, Cordelia's silence in the play marks the beginning of play's most problematic area. Her refusal to bow down to Lear's demand could be equated with Nature's rejection to be bounded. Therefore, for Lear, women are a space of danger and 
pollution- like Nature lacks reason and must be muted. Even in Cordelia's silence, Lear can hear something and that something is Cordelia's sense of authority even in her nothingness.

Nothingness of Cordelia and its ramification

In the play, Nature is exercising an ambivalent authority in male-female dichotomy to either condemn or sanction. That is why Lear thinks that Nature is favoring his daughters and the elements are "servile ministers" (3.2.21) that join "in battles 'gainst a head/ So old and white as [his]" (11.23-4). Nature and women are both seen as agents who on attaining free will could pose a threat to misogynistic Lear as evident in his refusal to accept Cordelia's "nothing." Both Nature and women are portrayed in extreme terms of saint and demon, silent and noisy, with almost little to no space for neutrality in between. Their positioning as an object raises structural and thematic concerns in the play. Lear's inability to allow Nature and women to have a voice and be in control stems from his anxieties about masculine identity, relentlessly abused by not only Goneril and Regan but also Nature. The unmapped spaces of the natural environment could be equated with the issue of "nothing" in King Lear as their existence signify resistance to domestication and Lear's attempt at controlling spaces. As women of the play, Nature is voiceless, except when seen as a threat, representing a masculine desire for control and hence, becomes an object to be managed. Cordelia's "nothing" signifies something "which nor our nature nor our place can bear" (1.1.171). For Lear, authority and its subversion- filial or political- is the core basis of Nature. Lear's desire for control is impossible to be achieved in Cordelia's "nothing" and an absence of blind support in Kent.

When Lear calls Cordelia a stranger, he is not only removing her from space that Lear recognizes as home but also against the law of Nature. For Lear, like Nature, Cordelia represents a hostile space whose silence does not show or confirm Lear's culture and society. 
Although by the end, he can shakily gain his identity and talk about his state's uncertainty"Would I were assur'd/ Of my condition" (4.7.55-6), he laments. Lear remains at the mercy of Nature and shows little change. He is still unable to understand Cordelia or accept the conditions of her love. His bizarre image of them in prison is of lovers and not of a father and a daughter, something not offered by Cordelia- "We two alone will sing like birds i'th'cage, $/ . . . "$ He says-

"So we'll live.

And pray, and sing, and tell old tales, and laugh

At gilded butterflies, and hear poor rogues

Talk of court news; and we'll talk with them too-

Who loses and who wins; who's in, who's out-

And take upon 's the mystery of things

As if we were God's spies; and we'll wear out.

In a wall'd prison, packs and sects of great ones.

That ebb and flow by th' moon." (11.9,11-19)

He is fantasizing about an ideal natural world that does that matches up to the grim reality of his experiences. He is blissfully dreaming about a daughter within confined space who will provide him with undivided attention and unconditional love as, initially, deceitfully preached by Goneril and Regan and denied by Cordelia in her silence.

\section{Conclusion}

It would be befitting to say that King Lear is about the dynamics of power and authority as it is about the natural world. In refusal to perceive Nature and women as more than masculine objects of desire, there occurs a reversal of natural order. With men like Lear losing their position, authority and even sanity to hold on to the last shreds of masculine 
control, there hides perverse and persistent anxiety about the phallic power with an ultimate desire to rule. 


\section{Works Cited}

Estok, Simon C. Ecocriticism and Shakespeare: Reading Ecophobia. US: Palgrave Macmillan, 2011.

Danby, John F. Shakespeare's Doctrine of Nature: A Study of King Lear. London: Faber \& Faber, 1948.

Kao, Grace Y. "The universal versus the Particular in Ecofeminist Ethics". The Journal of Religious Ethics, 38 (4), 2010: 616-637.

Plumwood, Val. Feminism and the Mastery of Nature. Canada: Taylor \& Francis e-library, 2003.

Shakespeare, William. King Lear. London: Arden Shakespeare, 1997.

Waage, Fred. "Review: Three Studies in Shakespeare Ecocriticism”. South Atlantic Review, 77 (2), 2012: 204-222. 